\section{Do Plant Guarantees Matter? The Role of Satisfaction and Regret when Guarantees are Present}

\author{
Jennifer H. Dennis, ${ }^{1}$ Bridget K. Behe, ${ }^{2}$ R. Thomas Fernandez, ${ }^{3}$ \\ and Robert Schutzki ${ }^{2}$ \\ Michigan Agricultural Experiment Station and Department of Horticulture, \\ Michigan State University, East Lansing, MI 48824-1325
}

\author{
Thomas J. Page, Jr. ${ }^{3}$ and Richard A. Spreng ${ }^{3}$ \\ Department of Marketing and Supply Chain Management, Michigan State \\ University, East Lansing, MI 48824-1325
}

Additional index words. consumer satisfaction, guarantees, hanging baskets, perennials, regret, potted rose, survey

\begin{abstract}
A consumer research study was conducted examining effects of plant guarantees on satisfaction and regret in the purchase of three horticultural products: hanging baskets, potted roses, and container perennials. Five hundred and seventeen respondents were divided into two groups: those who were offered a guarantee and those who were not offered a guarantee. The effects of satisfaction and regret on repurchase intentions were recorded on multi-item seven-point Likert scales. A structural equation model was used to examine simultaneous relationships between regret, satisfaction, and intention to repurchase. Survey results indicated guarantees would increase satisfaction and decrease regret for hanging baskets, but not for container perennials and potted roses. Five of six models showed regret and/or satisfaction directly impacted intention to repurchase. Both satisfaction and regret had a direct influence on repurchase intentions for the hanging baskets model regardless of the presence or absence of guarantees. When guarantees were absent, satisfaction and regret had direct effects on intention to repurchase for the perennial model. Regret was the only construct to directly impact intention to repurchase in the potted rose model. Guarantees appear to lower the risks of buying some products and may improve the perception of quality of the offering.
\end{abstract}

Traditional horticultural retailers have lost market share as competition intensifies from nontraditional outlets such as mass-merchandisers and do-it-yourself stores (National Gardening Association, 2002). From 19951999, garden centers led other retailers as the top place from which consumers purchased lawn and gardening products. In 2000, home centers surpassed garden centers for the top spot with garden centers in second and mass merchandisers a close third (National Gardening Association, 2001). As of 2002, 37 million households bought lawn and gardening products from garden centers, down from 39 million in 2001, representing a decrease of 5\% (National Gardening Survey, 2002). These data show that nontraditional outlets may be offering profitable products once only offered by garden centers. Pressure from the competition has challenged many traditional retail garden centers to seek creative ways to remain profitable. In what ways could horticulture customers perceive value in

Received for publication 16 Mar. 2004. Accepted for publication $25 \mathrm{Apr}$. 2004. Research conducted at Michigan State University, East Lansing, Michigan. The authors thank Michigan Nursery \& Landscape Association for partial funding of this project and R. DanielLineberger at TexasA\&MUniversity for helping coordinate and collect data for the Internet survey.

${ }^{1}$ Former doctoral candidate. Currently assistant professor, Purdue University. To whom reprint requests should be sent; e-mail jhdennis@ purdue.edu.

${ }^{2}$ Professor.

${ }^{2}$ Associate professor. the products of the traditional garden center? Increasing consumer satisfaction may be one competitive component, and one aspect of satisfaction may be to provide guarantees.

In past studies, researchers sought to improve profitability and consumer satisfaction of retail outlets by examining factors such as consumers' reason for choosing a particular retail outlet (Day, 1994). Garber and Bonadari (1998) identified opportunities to help retailers effectively merchandise plant material by examining better tags and labeling; better packaging and delivery; increased advertising assistance; pricing on pots; and point of purchase materials. Researchers also investigated the importance of plant attributes and store features including plant labels and signs; selection of products; knowledgeable staff; and healthy plant material as a way of improving marketing efforts within the horticulture retail sector (Behe and Barton, 2000; Brand and Leonard, 2001). In an effort to aid retail outlets, other studies have investigated plant quality and found it to be an important part of providing service quality by creating a competitive advantage within traditional retail garden centers. Plant quality accounted for $30 \%$ of a consumer's perceived service experience at garden centers patronized (Behe and Barton, 2000; Day, 1994). studied to gain a better understanding of what motivates customers to shop at garden centers. Niemiera et al., (1993) investigated what type of information customers used when select-
Effectiveness of plant guarantees has been ing plants. Consumers appear to find detailed information needed to identify and maintain plants followed by an unconditional guarantee as most important. Behe and Barton (2000) found consumers expected retailers to provide healthy plants, label variety and names, and provide plant guarantees. Researchers also found that retailers had the most difficulty with meeting customer expectations concerning the garden center's willingness to guarantee plants (Behe and Barton, 2000). Despite indirect measures showing plant guarantees were important to consumers, no one has explicitly quantified the effects of guarantees on a customer's perception of whether consumers will repurchase or stop buying plants based on their gardening experience. Using a survey approach, our goal was to evaluate the effect plant guarantees have on the level of consumer satisfaction and regret experienced with three horticultural products: hanging baskets, perennials, and potted roses.

Guarantees. Most consumers realize at least some risk is involved when they consider buying any good or service. Efforts to increase their success rate are made by evaluating salient characteristics and product attributes. Some may consider package labels to select the right product for the right use. However, what occurs when products lack the cues to produce sufficient information to reassure the customer, who may lack some knowledge or experience, that their choice to buy was correct? Some products can only be evaluated after purchase (e.g., experience products) and are extremely vulnerable to unfavorable selections. This may inhibit or challenge a consumers' choices because there is uncertainty about whether the product will perform as expected.

Kirmani and Rao (2001) showed that one solution for lowering the potential disappointment with an experience good was to use signals such as brand name, price, warranties, and moneyback guarantees now shown on promotional materials such as packaging. These signals indicate a certain level of quality associated with the product and are costless to the retailer at the time of offering. Guarantees serve as a source of product (or retailer) differentiation, provide a means for decreasing risk with experience goods, and provide a supplement to signal quality attributes about the particular product (Moorthy, 1995). Money-back guarantees are short-term remedies that offer a full or partial refund in a limited period of time, usually less than 30 days. Guarantees are differentiated from warranties because the latter cover longer time periods (e.g., 3 to 5 years) and often are used for repairs or replacements and do not involve refunds. Although gardening plants can be categorized as "experience goods," money-back or plant guarantees have not been prominently used or promoted in the retail horticulture industry.

The goal of this research was to examine the influence of plant guarantees on satisfaction and regret based on the actual experience associated with the product. Satisfaction was evaluated based on comparisons between performance and expectations. Regret was operationalized as a negative emotion that results after an undesirable appraisal of an event. Regret can be affected by intensity factors such as the degree to which 


\section{Guarantee Present}

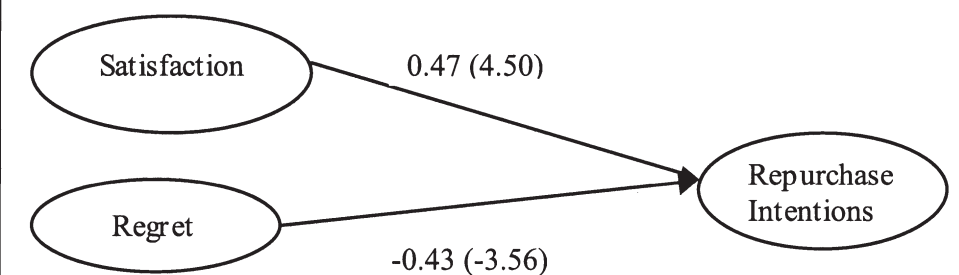

$-0.43(-3.56)$

Statistics tor the model: $\chi=235,40, \mathrm{dt}=51$ Root Mean Square Error Approximation (RMSEA) $=0.15$, Normed Fit Index $(\mathrm{NFI})=0.95$, Comparative Fit Index $(\mathrm{CFI})=0.96$, Adjusted Goodness Fit Index (AGFI) $=069$

\section{Guarantee Absent}

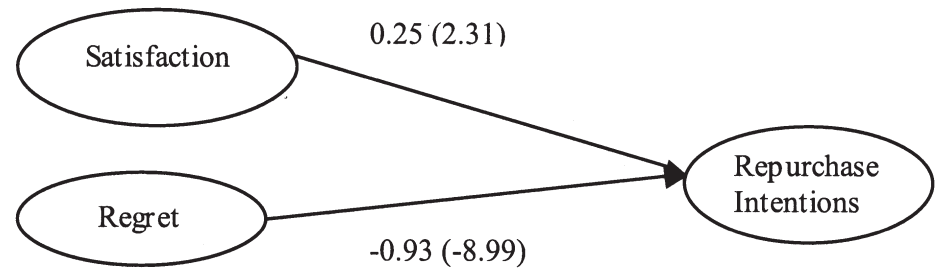

Statistics for the model: $\chi=241.37$, d. $=51$, Root Mean Square Error Approximation (RIMSEA) $=0.15$, Normed Fit Index $(\mathrm{NFI})=0.93$, Comparative Fit Index $(\mathrm{CFI})=0.93$, Adjusted Goodness of Fit Index $(\mathrm{AGFI})=0.70$

Fig. 1. Satisfaction and regret models measuring the effect of repurchase intentions for hanging baskets.

the event is unexpected (Dennis et al., 2004a; Ortony et al., 1988). This study also examined the direct effects of satisfaction and regret on repurchase intentions. Repurchase intentions were measured as the consumer's willingness to buy again based on previous experiences with the same or similar product.

We hypothesized that the strength of the relationship for regret on intentions would decrease when guarantees were given for the three plants purchased (H1). Hypothesis two stated the strength of the relationship for satisfaction on intentions would increase when guarantees were provided (H2). Our final hypothesis stated that regret and satisfaction with the purchase of the three plants would have direct effects on repurchase intentions (H3).

\section{Materials and Methods}

In September 2003, a consumer research study was conducted by obtaining an email database maintained by Survey Sampling, Inc. (Farifield, Ct.) and inviting individuals from the list to take part in an Internet-based survey.
The research study was approved by the Institutional Review Board for Protection of Human Subjects at Michigan State University before implementation. Respondents were asked to qualify themselves by responding to questions about whether they had purchased certain types of ornamental plants suitable for gardening use. Respondents qualified if they purchased one of three outdoor plant products (hanging basket, potted roses, or container perennials). Those respondents who did not qualify were sent to a screen thanking them for their time. Qualifying responses were then submitted to a FilemakerPro database (Santa Clara, Calif.), which returned the email address associated with the survey when the appropriate choices were selected. To prevent participants from browsing back to guess the right response, the server placed a cookie in the respondent's browser when the qualification was denied, which prevented resubmission of the qualification form. Qualified participants were sent to a different screen to answer questions based on their observations and experiences regarding the particular plant(s) (eitherhanging basket, potted rose, or perennial) they purchased in 2003 . Once qualified, respondents answered questions for which a response was required for almost all fields (with the exception of two open-ended questions asking for optional explanations of plant buying behavior) or an error message was generated. The last input on the survey required the respondent's email address. A note placed prominently near the input line indicated that their email would be secured and only used for correspondence about the honorarium, a $\$ 5$ ecoupon redeemable at Amazon.com.

In total, 18,666 individuals were invited to participate in the survey. The survey was closed after receiving 777 responses during five hours in a one-day period, representing a $4 \%$ response rate. The decision to terminate was based on costs for incentives and when an acceptable number of surveys were obtained for appropriate data analysis. After removing unusable surveys based on incomplete responses, 743 remained. Participants ranged in age from 18 to 76 years with a mean age of 39 years. Participants were predominately $(74 \%)$ female and had completed a mean of 15 years of education. Forty-one percent of the participants had completed 16 or more years of formal education, or the equivalent of a Bachelor's degree. Of the participants, $58 \%$ had a 2002 household income of $\$ 25,001$ to $\$ 70,000$ with a mode of $\$ 25,001$ to $\$ 50,000$ (30\%). The typical household had a mode of two persons (68.8\%) with no children $(37.7 \%)$. Participants residing throughout the U.S. population participated with $46 \%$ responding from the midwestern U.S. The largest number of responses came from Illinois (18\%), Ohio (17\%), and California (17\%). According to the National Gardening Association (2002), gardeners who participated in flower gardening were $46 \%$ female; with $51 \%$ between the ages of 35 and 44 and $46 \%$ between the ages of 45 and 54; had some college or were college graduates; $44 \%$ earned $\$ 35$ to $\$ 49,999 ; 43 \%$ were married with children.

Evaluation of reliability and validity of multiple measure constructs was performed using confirmatory factor analysis (CFA) and Cronbach's alpha. All constructs were measured with seven-point Likert scales. Satisfaction, regret, and repurchase intentions were measured using four survey questions each with alpha values of $0.95,0.96$, and 0.85 respectively. All reliability values exceeded Nunnaly's (1978) lower threshold of 0.70 for such scales. A CFA was conducted to assess the reliability and validity for the three constructs used in each model using Lisrel 8.5 structural equation modeling software (Jöreskog and Sörbom, 2003).

Only those respondents who experienced some amount of regret were included in the analysis, resulting in the use of 517 cases. Six structural models were evaluated using Lisrel 8.5 (Jöreskog and Sörbom, 2003). Each horticultural product (hanging basket, container perennial, and potted rose) was analyzed separately using two groups: those that had guarantees (hanging basket $\mathrm{n}=112$, container perennials, $\mathrm{n}=104$, potted roses $n=54$ ) and those that did not (hanging basket $n=117$, container perennials, $n=56$, potted roses $n=53$ ). Twenty one respondents did not specify whether a guarantee had been 


\section{Guarantee Present}

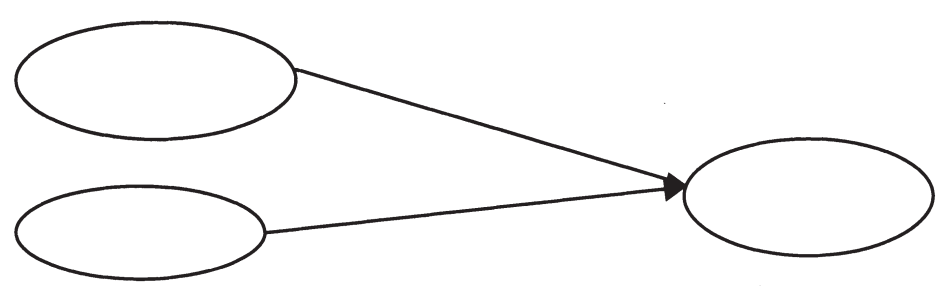

Statistics or the model: $\chi=39.52, \mathrm{dt}=51$, Root Mean Square Error Approximation $(\mathrm{RMSEA})=0.00$, Normed Fit Index $(\mathrm{NFI})=0.95$, Comparative Fit Index $(\mathrm{CFI})=1.00$, Adjusted Goodness of Fit Index $(\mathrm{AGFI})=0.94$

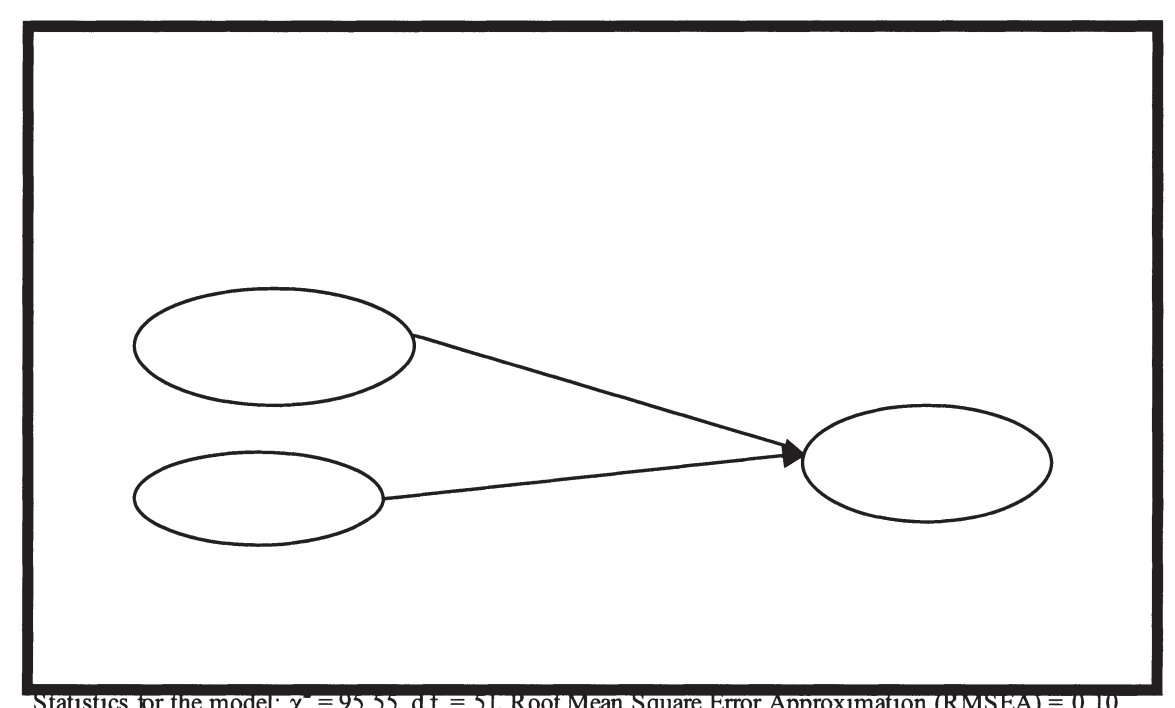

or the model. $\chi=95$ $(\mathrm{AGFI})=0.73$.

Fig. 2. Satisfaction and regret models measuring the effect of repurchase intentions for container perennials.

given and were eliminated from the analysis $(n=496)$. The fit statistics for the six models indicated a satisfactory fit for all models because the chi square to degrees-of-freedom ratios were within the appropriate levels and all goodness of fit measures met the appropriate minimum levels except for adjusted goodness of fit index (Figs. 1, 2, and 3) (Bagozzi and Yi, 1998).

\section{Results and Discussion}

Gardening enjoyment and experience. The mean for gardening enjoyment was 5.5 out of 7.0 , indicating on average most participants liked gardening. Gardening knowledge and enjoyment were positively correlated $(r=0.64)$ meaning as gardening knowledge increased gardening enjoyment would increase as well. Gender comparisons showed no difference between male and female respondents on the seven-point Likert scale measuring enjoyment (chi square $=8.19, p=0.23)$. However, the overall finding was consistent with that of Hardy et al. (1999), who found that more female gardeners indicated that they enjoyed gardening and considered themselves plant experts than did males.

Dollars and time spent in the garden. We also asked how much time and money was spent on annual and perennial plants in 2002. Answers ranged from $\$ 0$ to $>\$ 101$ for both annuals and perennials, with a mode of $\$ 21$ to $\$ 30(15.6 \%)$ for annuals and $\$ 21$ to $\$ 30(14.3 \%)$ for perennials. The second most frequent response for annuals was $\$ 11$ to $\$ 20(14 \%)$ and $>\$ 101(12.1 \%)$ for perennials. Expenditures on annuals and perennials were less than expenditures of $\$ 74$ on flower gardening reported for 2002 by the National Gardening Association. Respondents were also asked to identify how many hours per week they typically spent in the gardens, with responses ranging from 0 to $>10 \mathrm{~h}$. The mode was $>10 \mathrm{~h}(22.9 \%)$ with the next highest category at $3 \mathrm{~h}(13.9 \%)$.

Guarantees. We hypothesized that the effect of regret would decrease when guarantees were present $(\mathrm{H} 1)$. The hypothesis was supported for hanging baskets only. When guarantees were provided for hanging baskets, the effect of regret on intentions decreased (Table 1). The perennial and rose models had different results showing no significant change in the level of regret when guarantees were provided (Table 1). We also hypothesized that the effect of satisfaction would increase when guarantees were present $(\mathrm{H} 2)$. This was supported for the hanging basket model (Table 1). The perennial model showed that satisfaction decreased when guarantees were given and the level of satisfaction did not significantly change for the potted rosemodel(Table 1).Lastly, we hypothesized that satisfaction and regret had direct effects on intentions to repurchase (H3). This was supported for hanging baskets (Fig. 1). The effect of regret and satisfaction experienced did affect consumers' likelihood to purchase this product again.

In the perennial model, satisfaction had a direct effect on intentions to repurchase only when guarantees were not given (Fig. 2). When guarantees were provided, intention torepurchase was really determined by regret, and as regret increased, intention to repurchase decreased, as was the case for the potted rose. This may be influenced by the amount of time and money invested because there is an observed difference between the hanging baskets (which may be an annual plant or short-term investment) and the perennials that are greater time and or money investments. These results indicated consumers may view guarantees as necessities and they may, in some cases neutralize the effect of regret, when products fail to meet desires. In other words, when no safety net was in place, an undesirable outcome may affect consumer's willingness to repurchase. Consumers may feel entitled to guarantees for gardening products because there are few industries that do not provide them.

Regrethad a stronger effect on intention to repurchase for both the guarantee and no guarantee model indicating the level of regret experienced would be a factor when consumers repurchase products. Regret was stronger on intentions for potted roses, compared to hanging baskets and containerperennials, both, when guarantees were absent or present (Fig. 3). This makes intuitive sense because those customers that experienced regret had a strong emotional response attributed to self-responsibility and had a need to redo or undo the situation. Regardless of a guarantee, those customers that experienced regret would be less likely to repurchase. Regret is such a strong emotion that it leads to harsh consequences such as consumers choosing another product (Dennis et al., 2004b) or retailers finding a way to entice customers to repurchase again.

\section{Conclusions}

Independent retail garden centers have lost market share to mass merchandisers and home stores, but they remain among the top three types of retail outlets visited (National Gardening Association, 2002). Consumers may be looking for a way to differentiate and assess quality with experience goods such as gardening products. The potential to use plant guarantees to create this distinguishing characteristic may be an option. Future research should focus on the cost of guarantees to the retail establishment. 


\section{Guarantee Present}

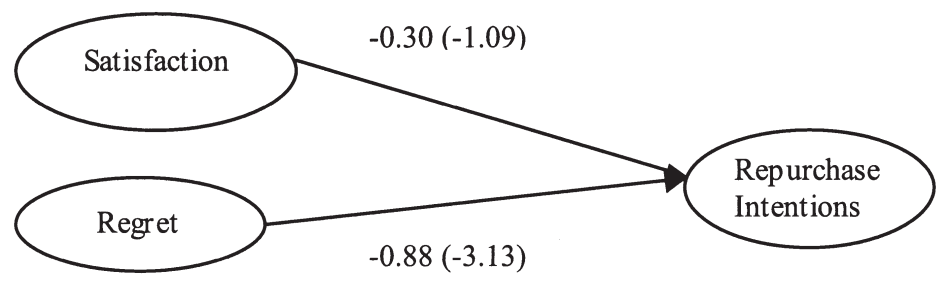

Stistics tor the model: $\alpha=141,19, \mathrm{dt}=51$, Root Mean Square Error Approximation (RIMSEA) $=0.16$, Normed Fit Index $(\mathrm{NFI})=0.91$, Comparative Fit Index $(\mathrm{CFI})=0.93$, Adjusted Goodness of Fit Index $(\mathrm{AGFI})=0.61$

\section{Guarantee Absent}

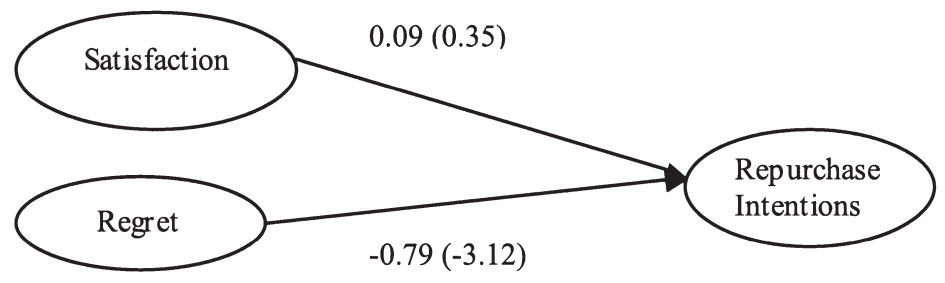

Statistics or the model: $\chi=50.15, \mathrm{df}=51$, Root Mean Square Error Approximation (RIMSEA) $=0.00$, Normed Fit Index (NFI) $=0.97$, Comparative Fit Index $(\mathrm{CFI})=0.99$, Adjusted Goodness of Fit Index $(\mathrm{AGFI})=0.82$

Fig. 3. Satisfaction and regret models measuring the effect of repurchase intentions for potted roses.

This survey used a national approach to examine levels of consumer satisfaction and regret consumers experienced when plant guarantees were given to three types of gardening products. Consumers experienced stronger relationships with satisfaction and decreased effects of regret with hanging baskets when guarantees were provided. This shows guarantees are influential and provide value to consumers when making decisions regarding these purchases. Increasing value and decreasing the level of the effects of guarantees on different products. Independent garden centers may be able to maximize their competitiveness by positioning plant guarantees as a signal of excellent plant quality for selected plants.

\section{Literature Cited}

Bagozzi, R.P. and Y. Yi. 1988. On the evaluation of structural models. J. Acad. Mktg. Sci. 16:1, 74-94.

Behe, B. and S. Barton. 2000. Consumer perceptions of product and service quality attributes in six U.S. States. J. Environ. Hort. 18:71-78.

Brand, M.H. and R.L. Leonard. 2001. Consumer product and service preferences related to landscape retailing. HortScience 36:1111-1116.

Day, E. 1994. An exploratory study of garden center selection for landscape plants. J. Environ. Hort. 12:142-146.

Dennis, J.H., T.J. Page, Jr., R.A. Spreng, and B.K. Behe. 2004a. The determinants of regret in consumer purchase situations. Amer. Mktg. Assn. Summer Educ. Conf. Proc. (in pressg).

Dennis, J.H., R.A. Spreng, T.J. Page, Jr., and B.K. Behe. 2004b. What happens after product failure: An examination of switching as the behavioral consequence of regret. $\mathrm{PhD}$ diss. Mich. State Univ.

Garber, M.P. and K. Bondari. 1998. Retail garden outlets: Plant material purchases and trends. J. Environ. Hort. 16:20-26.

Hardy, J., B. Behe, and T. Page. 1999. Consumer segmentation based on perceived plant knowledge and gardening involvement. Proc. S. Nurserymen's Assn. 44:529-532.

Jöreskog, K.G. and D. Sörbom. 2003. LISREL 8.5: User's reference guide. Scientific Software, Mooresville, Ind.

Kirmani, A. and A.R. Rao. 2001. No pain, no gain: A critical review of the literature on signaling unobservable product quality. J. Mktg. (April):66-79.

Moorthy, S. and K. Srinivasan. 1995. Signaling quality with a money-back guarantee: The role of transaction costs. Mktg. Sci. 14:4, 442-466.

National Gardening Association. 2001-2002. National gardening survey. Natl. Gardening Assn., Burlington, Vt.

National Gardening Association. 2000-2001. National gardening survey. Natl. Gardening Assn., Burlington, $\mathrm{Vt}$.

Niemiera, A.X., J. Innis-Smith, and C.E. Leda. 1993. Survey of garden center customer informational and marketing needs. J. Environ. Hort. 11:25-27.

Nunnally, J.C. 1978. Psychometric theory. McGrawHill, New York.

Ortony, A., G.L. Clore, and A. Collins. 1988. The cognitive structure of emotions. Cambridge Univ. Press, Cambridge, U.K.

Table 1. Parameter values for hanging basket, container perennial, and potted rose models; $t$ values over 2.00 are considered statistically significant.

\begin{tabular}{|c|c|c|c|c|}
\hline \multirow[b]{2}{*}{$\begin{array}{l}\text { Path } \\
\text { (hypotheses) }\end{array}$} & \multicolumn{2}{|c|}{ Coefficients ( $t$ values) } & \multirow[b]{2}{*}{ Change } & \multirow[b]{2}{*}{ Outcome } \\
\hline & $\begin{array}{l}\text { Absent } \\
\text { guarantees }\end{array}$ & $\begin{array}{l}\text { Present } \\
\text { guarantees }\end{array}$ & & \\
\hline \multicolumn{5}{|l|}{ Hanging baskets } \\
\hline Regret to $\mathrm{RI}^{\mathrm{z}}(\mathrm{H} 1)$ & $-0.93(-8.99)$ & $-0.43(-3.56)$ & - & Effect of regret decreased with a guarantee \\
\hline Satisfaction to RI (H2) & $0.25(2.31)$ & $0.47(4.50)$ & + & Effect of satisfaction increased with a guarantee \\
\hline \multicolumn{5}{|l|}{ Container perennials } \\
\hline Regret to RI (H1) & $-0.54(-2.92)$ & $-0.62(-3.38)$ & + & Effect of regret increased with a guarantee \\
\hline Satisfaction to RI (H2) & $0.44(2.37)$ & $0.05(0.52)$ & - & Effect of satisfaction decreased with a guarantee \\
\hline \multicolumn{5}{|l|}{ Potted roses } \\
\hline Regret to RI (H1) & $-0.79(-3.12)$ & $-0.88(-3.13)$ & + & Effect of regret increased with a guarantee. \\
\hline Satisfaction to RI (H2) & $0.09(0.35)$ & $-0.30(-1.09)$ & + & Effect of satisfaction increased (not significantly) with a guarantee. \\
\hline
\end{tabular}

${ }^{\mathrm{z}} \mathrm{RI}=$ repurchase intentions. 